\title{
Antibody-Drug Conjugate Therapy
}

National Cancer Institute

\section{Source}

National Cancer Institute. Antibody-Drug Conjugate Therapy. NCI Thesaurus. Code C15508.

Treatment with injections of therapeutic substances linked with specific antibodies in order to directly destroy specific, usually cancerous, cells or to stimulate the immune system to destroy those cells. 